\title{
Interaction between human polymorphonuclear leucocytes and bacteria released from in-vitro bacterial biofilm models
}

\author{
H. YASUDA, Y. AJIKI, J. AOYAMA and T. YOKOTA* \\ Biological Research Laboratories, Sankyo Co. Ltd, 2-58 Hiromachi 1-chome, Shinagawa-ku, Tokyo 140 \\ and * Juntendo College School of Medical Technology, 2-2 Takasu, Urayasu-shi, Chiba 279, Japan
}

\begin{abstract}
Summary. The interactions between phagocytic cells (polymorphonuclear leucocytes) and Escherichia coli cells released from a biofilm model formed in vitro on the surface of cotton threads in an artificial medium were compared with those of phagocytes and bacteria released from a newly developed in-vitro biofilm model. This new model of bacterial biofilm on the surface of cotton threads was developed by soaking cotton threads in rat carboxymethylcellulose pouch exudate and culturing $E$. coli in the exudate. The structure of the biofilm model and the surface structure of the bacteria in the biofilm resembled those observed in vivo in infected pouches, and they were quite different from those observed with the biofilm model in artificial medium. Both bacteria released from biofilm models in an artificial medium and those from biofilms in rat carboxymethylcellulose pouch exudate, in vitro, were almost equally resistant to killing by phagocytes. The sensitivity of these bacteria to phagocytosis was no different from that of normal bacteria grown in artificial medium. Bacteria from both models were also less sensitive to the killing activity of $\mathrm{H}_{2} \mathrm{O}_{2}$. Electronmicroscopy showed that bacteria from both models had some products that interacted with ruthenium red on their surfaces, but the respective quantities of these products differed.
\end{abstract}

\section{Introduction}

Bacteria in biofilms are a major concern for clinicians in the treatment of infections because of their resistance to a wide range of antibiotics. ${ }^{1-3}$ Biofilms have been found on the surface of implanted biomaterials $^{4-6}$ and tissues ${ }^{7-10}$ in chronic bacterial diseases that are characterised by resistance to chemotherapy ${ }^{11-14}$ and they are resistant to clearance by humoral or cellular host defence mechanisms. ${ }^{15-17}$ Despite several investigations of the increased resistance of biofilm bacteria to phagocytosis, ${ }^{16,17}$ the mechanisms of the resistance of biofilm bacteria to the activity of phagocytes are still obscure.

Experimental bacterial biofilms have been formed on the surface of disks of silicone latex catheter material ${ }^{18}$ or on cellulose acetate membranes ${ }^{19,20}$ by culturing bacteria in an artificial medium. Nickel et al. ${ }^{2}$ formed "biofilms" on the surface of disks of urinary catheter material by culturing bacteria in artificial urine. However, more detailed investigations on the mechanisms of resistance of biofilm bacteria to antibiotics or host defence mechanisms require a com-

Received 8 Dec. 1992; revised version received 20 Jan. 1994; accepted 1 June 1994. parative study in model systems that are different in nature from each other.

In this report, the sensitivity of bacteria released from a biofilm model formed in an artificial medium to the activity of phagocytes and the killing activity of $\mathrm{H}_{2} \mathrm{O}_{2}$, was compared with that of bacteria released from a newly developed in-vitro bacterial biofilm model.

\section{Materials and methods}

\section{Animals}

Male Wister-Imamichi rats weighing $140-150 \mathrm{~g}$ purchased from Imamichi Institute for Animal Reproduction (Saitama, Japan) were used. Rats were acclimatised for 5-7 days before use in a room with an environment of controlled temperature and relative humidity, and a 12-h light-dark cycle.

\section{Bacteria}

Escherichia coli strain.704, a clinical isolate maintained in our laboratory, was cultured in TrypticaseSoy Broth (TSB; Eiken-kagaku Co., Ltd, Tokyo, Japan) at $37^{\circ} \mathrm{C}$ for $20 \mathrm{~h}$ before use. 


\section{Human polymorphonuclear leucocytes (PMNL)}

Human PMNL were harvested and purified according to the methods of Zimmerli et al. ${ }^{21}$ Heparinised blood $(60 \mathrm{ml})$ from a healthy volunteer was mixed with an equal volume of phosphatebuffered saline (PBS) containing dextran T500 (Pharmacia AB, Uppsala, Sweden) 3.5\% and left at room temperature for $45 \mathrm{~min}$. The white blood cell layer was collected and centrifuged at $1300 \mathrm{rpm}$ for $5 \mathrm{~min}$ at $4^{\circ} \mathrm{C}$. The precipitated cell fraction was washed once with $10 \mathrm{ml}$ of Eagle's Basal Medium (EBM; Nissui-seiyaku Co., Ltd, Tokyo, Japan) by centrifugation at $4^{\circ} \mathrm{C}$. Cells were resuspended in $4 \mathrm{ml}$ of EBM. The suspension was added gently to $4 \mathrm{ml}$ of FicollPaque solution (Pharmacia AB, Uppsala, Sweden) and centrifuged at $1300 \mathrm{rpm}$ for $30 \mathrm{~min}$ at room temperature. The PMNL fraction was collected; $90 \%$ of the cells in the PMNL fraction were neutrophils.

\section{Human serum}

Human serum was obtained from fresh blood of a healthy volunteer. The serum was heated at $56^{\circ} \mathrm{C}$ for $40 \mathrm{~min}$ before use.

Formation of pouches on the backs of rats, extraction of pouch exudate, induction of infection and in-vitro formation of bacterial biofilm on the surface of cotton threads

The methods used were described previously by Ajiki et al. ${ }^{10}$ An air pouch on the back of a rat was formed by injecting $10 \mathrm{ml}$ of air subcutaneously with a 21 -gauge needle after trimming off the hair with a hair clipper. Just after removal of the needle, the needle hole in the skin was sealed with an adhesive agent. The next day, under anaesthesia, the air in the pouch was aspirated and a carboxymethylcellulose (CMC) pouch was formed by injecting $10 \mathrm{ml}$ of sterilised CMC (Daiichi Pure Chemicals Co., Ltd, Tokyo, Japan) $1.5 \%$ in saline. The pouch exudate which was used for the formation of biofilms in vitro was extracted with a syringe $7 \mathrm{~h}$ after the injection of CMC (about $7 \mathrm{ml}$ of exudate could be extracted from a pouch). An infection was induced by inoculating $1 \times 10^{7} \mathrm{cfu}$ of $E$. coli strain 704 into a pouch along with the CMC.

Sterilised cotton threads (no. 6, Suzuki-thread, Tokyo, Japan), $1 \mathrm{~mm}$ in diameter, were soaked in $5 \mathrm{ml}$ of TSB or the pouch exudate, and $5 \times 10^{6} \mathrm{cfu}$ of $E$. coli were added. The mixtures were incubated at $37^{\circ} \mathrm{C}$ for $24 \mathrm{~h}$. The threads were then transferred into fresh TSB or pouch exudate and incubated again. Threads which had received two repeated transfers, i.e. $72 \mathrm{~h}$ after the beginning of incubation, were used for the experiments (fig. 1).

\section{Preparation of biofilm bacteria}

Fig. 2 is a flow chart of the experiments. The cotton threads with biofilms on their surfaces were rinsed once with TSB, and then soaked in fresh TSB and incubated at $37^{\circ} \mathrm{C}$ for $30-60 \mathrm{~min}$ in a shaking apparatus. The critical incubation time was determined according to the turbidity of the TSB to control the number of planktonic bacteria (PB) released from the biofilm. The PB were used as biofilm bacteria in the following experiments. As a control in each experiment, bacteria which had been cultured in TSB at $37^{\circ} \mathrm{C}$ for $72 \mathrm{~h}$ were used.

\section{Sensitivity of PB to phagocytosis and phagocytic killing}

TSB $(0.25 \mathrm{ml})$, containing c. $3 \times 10^{7} \mathrm{cfu}$ of $\mathrm{PB} / \mathrm{ml}$, was mixed with EBM $0.55 \mathrm{ml}$, human serum $0.2 \mathrm{ml}$, $0.5 \mathrm{ml}$ of EBM containing $4 \times 10^{7} \mathrm{PMNL} / \mathrm{ml}$, and $0.5 \mathrm{ml}$ of EBM containing gelatin (Wako-junyaku Industry Co., Ltd, Tokyo, Japan) $4 \%$. For reaction mixtures without PMNL, $0.5 \mathrm{ml}$ of EBM was added in place of the PMNL suspension. The reaction mixtures were incubated at $37^{\circ} \mathrm{C}$ in a rolling incubator $(7 \mathrm{rpm})$. At 1 and $2 \mathrm{~h}$ after the beginning of incubation, the number of bacteria in a reaction mixture was counted on Heart Infusion Agar (Eiken-kagaku). Each experiment was repeated three times.

For measurement of the sensitivity of PB to phagocytosis, the reaction mixtures were centrifuged at $1300 \mathrm{rpm}$ for $5 \mathrm{~min}$ at $4^{\circ} \mathrm{C}, 15 \mathrm{~min}$ after the beginning of incubation. Precipitated PMNL were resuspended in a small amount of human serum and smeared on to glass slides. Phagocytosis was observed by microscopic examination of Wright-stained cell smears. One hundred neutrophil PMNL on each smear were examined, and the percentage of phagocytosing neutrophils and the mean number of bacteria/phagocytosing neutrophil were calculated. Each experiment was repeated five times.

\section{Sensitivity of $\mathrm{PB}$ to killing activity of $\mathrm{H}_{2} \mathrm{O}_{2}$}

A small amount of $\mathrm{H}_{2} \mathrm{O}_{2} \quad 31 \%$ solution (Iwai Kagaku Co., Ltd, Tokyo, Japan) was added to TSB containing c. $3 \times 10^{6} \mathrm{cfu}$ of $\mathrm{PB} / \mathrm{ml}$, to make the $\mathrm{H}_{2} \mathrm{O}_{2}$ concentration $0.01 \%$ or $0.001 \%$. The reaction mixtures were incubated at $37^{\circ} \mathrm{C}$ in a shaker. After $1 \mathrm{~h}$, numbers of viable bacteria were counted on heart infusion agar. Each experiment was repeated three times.

\section{Electronmicroscopy}

Scanning electronmicroscopy. Pieces of subcutaneous tissue from the infected CMC pouches and the cotton threads were processed for scanning electronmicroscopy by fixing for $90 \mathrm{~min}$ at $4^{\circ} \mathrm{C}$ in glutaraldehyde $2 \%$ in $0.1 \mathrm{M} \mathrm{PBS}, \mathrm{pH} 7 \cdot 4$, with sucrose $8 \%$. This was followed by re-fixation for $90 \mathrm{~min}$ at $4^{\circ} \mathrm{C}$ in osmic acid $2 \%$ in the same buffer, dehydration in a series of aqueous ethanol solutions (50-100\%), 

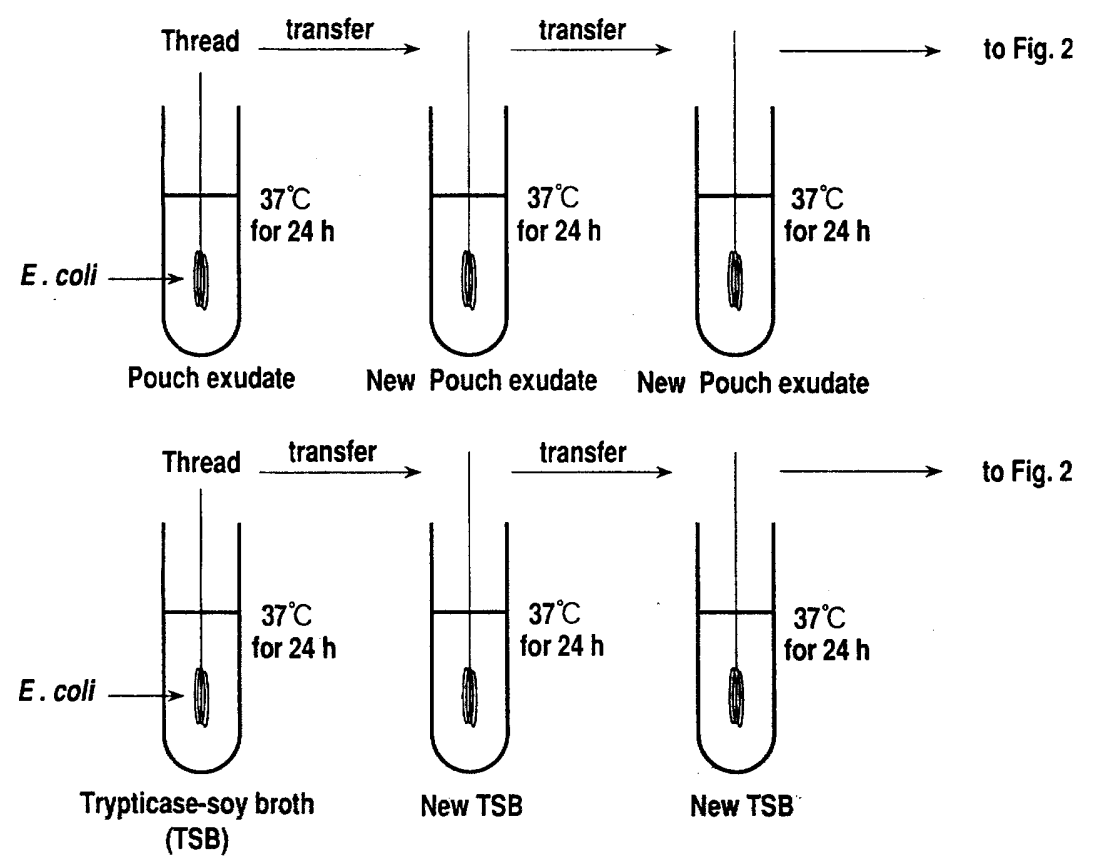

Fig. 1. Flowchart of experiments, 1.

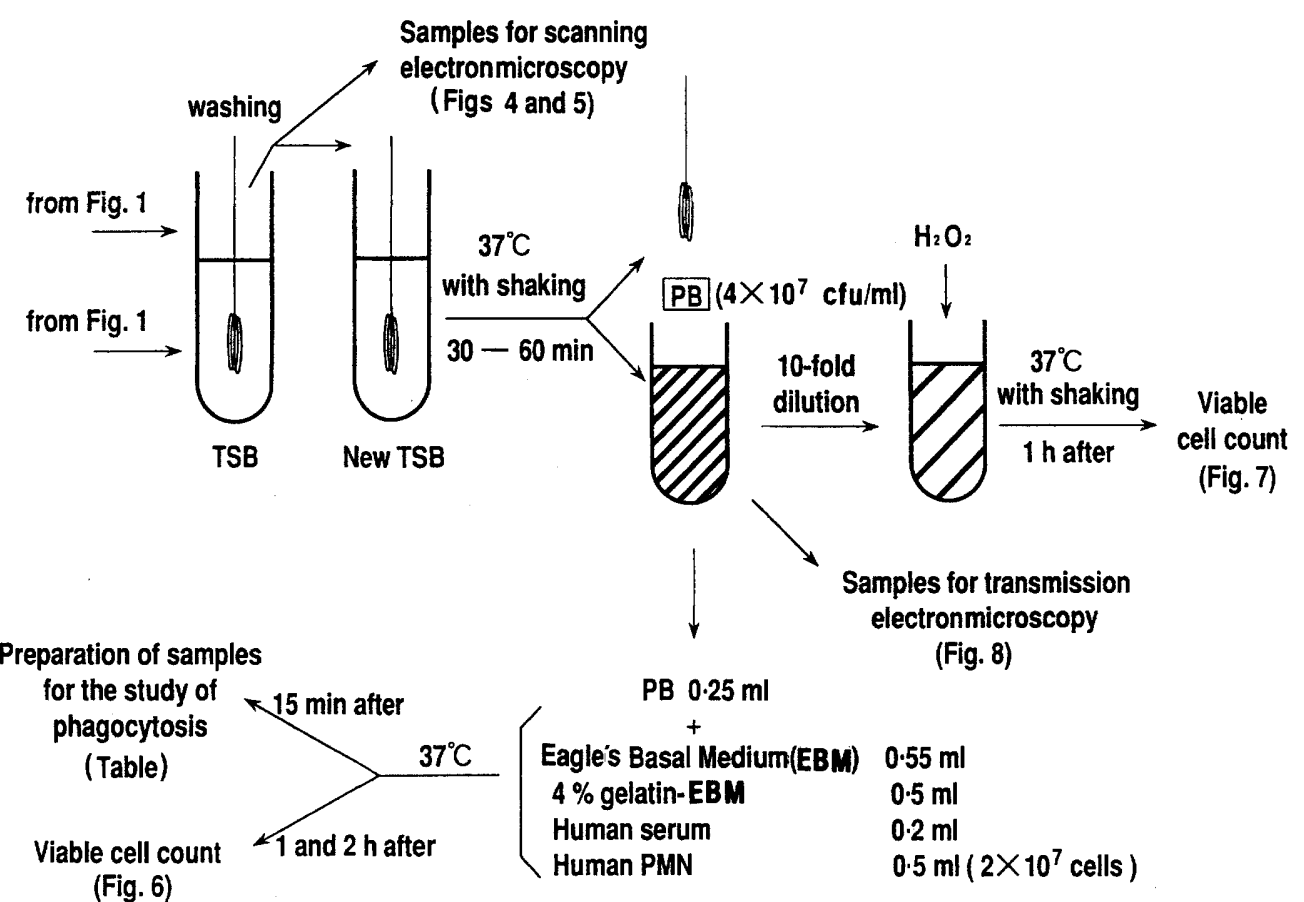

Fig. 2. Flowchart of experiments, 2.

and drying in a VFD-20 drying apparatus (HitachiSeisakusho Inc., Tokyo, Japan). Samples were then coated with platinum-palladium in an Ion-coater E-102 (Hitachi-Seisakusho) and examined with an S-4000 scanning electronmicroscope (HitachiSeisakusho).

Transmission electronmicroscopy. PB were collected by centrifugation and fixed for $2 \mathrm{~h}$ at $4^{\circ} \mathrm{C}$ in $0.66 \mathrm{M}$ cacodylate buffer, $\mathrm{pH} 7 \cdot 3$, containing glutaraldehyde $2 \%$ and ruthenium red (TAAB Laboratories Equip- ment Ltd, Berks) $0.005 \%$. The samples were then rinsed with cacodylate buffer and re-fixed for $3 \mathrm{~h}$ at room temperature in $0.66 \mathrm{M}$ cacodylate buffer containing $\mathrm{OsO}_{4} 2 \%$ and ruthenium red $0.005 \%$. Samples were rinsed with cacodylate buffer, then dehydrated in a graded series of alcohols and embedded in Epon 812. Sections were made with a diamond knife on a Sorvall MT6000 (Du Pont Company, DE, USA). The sections were stained for $15 \mathrm{~min}$ with uranyl acetate $2 \%$ followed by a 10-min treatment with lead citrate. The 
$24 \mathrm{~h}$
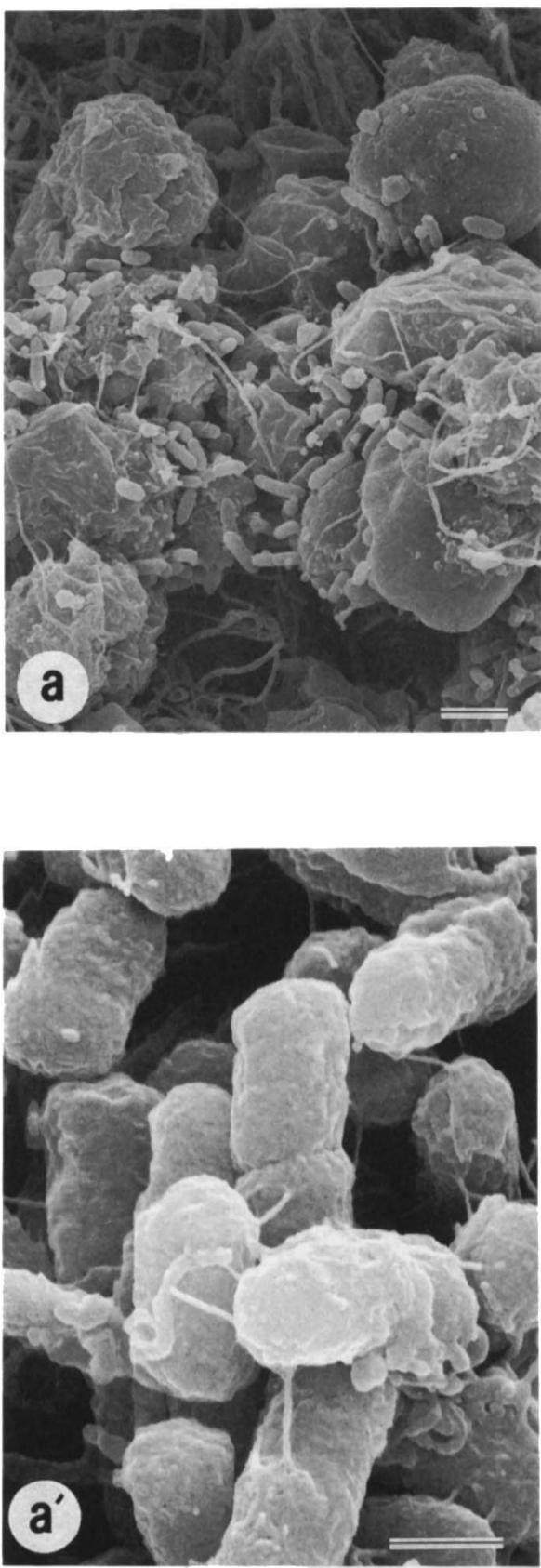

$48 \mathrm{~h}$
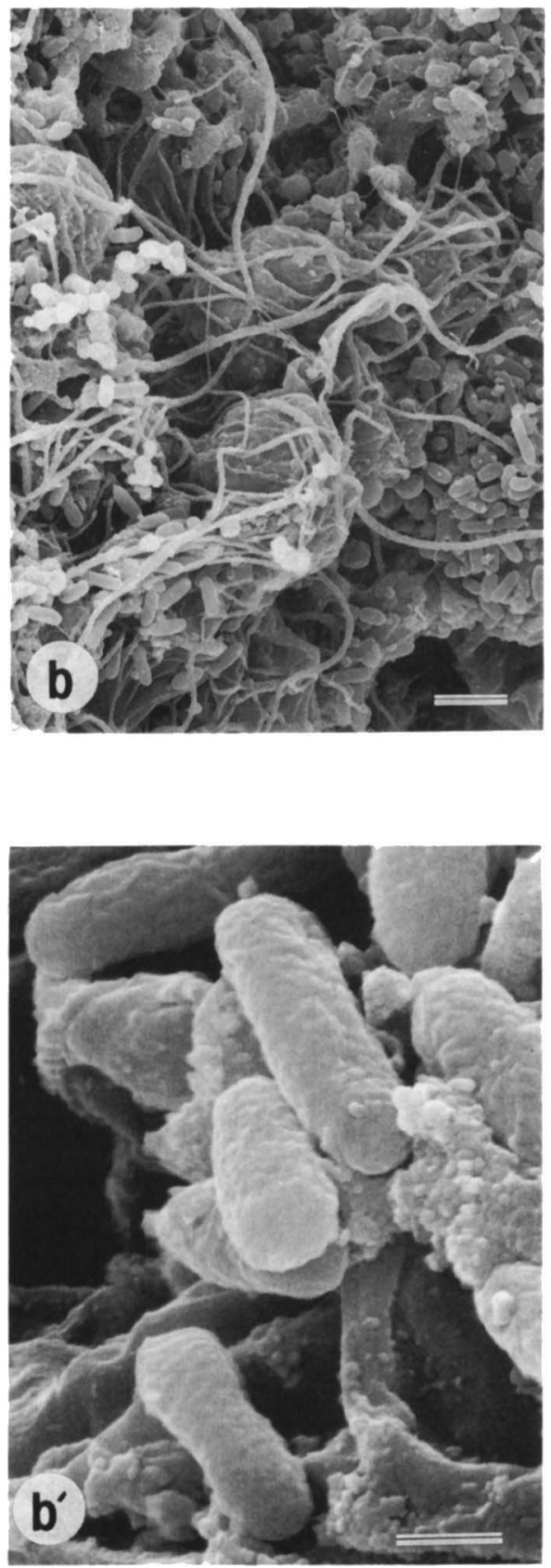

Fig. 3. In-vivo biofilm growth of $E$. coli in CMC pouches in rats. Scanning electronmicrographs of subcutaneous tissue of CMC pouches $24\left(\mathbf{a}, \mathbf{a}^{\prime}\right)$ and $48 \mathrm{~h}\left(\mathbf{b}, \mathbf{b}^{\prime}\right)$ after inoculation of $1 \times 10^{7} \mathrm{cfu}$ of $E$. coli. Bars in $\mathbf{a}, \mathrm{b}^{\prime}$ and $\mathbf{a}^{\prime}, \mathbf{b}^{\prime}$ are equivalent to $2 \mu \mathrm{m}$ and $0.5 \mu \mathrm{m}$, respectively.

electronmicrographs were made with an EM-100SX transmission electronmicroscope (Nihon-Denshi Co., Ltd. Tokyo, Japan).

\section{Results}

In-vivo biofilm model of growth of E. coli in CMC pouches in rats

The development of biofilm with time after infection of CMC pouches of rats with $E$. coli is shown in figs. 3a and $b$ which, respectively, show the electronmicrographs of subcutaneous tissue at 24 and $48 \mathrm{~h}$ after infection. It can be seen that many blood cells and some other cells, complicated fibrous structures and bacteria, in one body, make the colonising biofilm of bacteria progressively larger and thicker. Figs. $3 a^{\prime}$ and $b^{\prime}$ show the surface structures of bacteria in the biofilms corresponding to figs. $3 a$ and $b$. The surface structures of the bacteria gradually became complex.

In-vitro biofilm model of growth of $E$. coli on the surface of cotton threads in artificial medium or pouch exudate

Figs. 4a-c and 5a-c show the development of biofilm structures on the surface of cotton threads in TSB and exudate from CMC pouches, respectively. In both 


\section{Transfer repetitions}

0

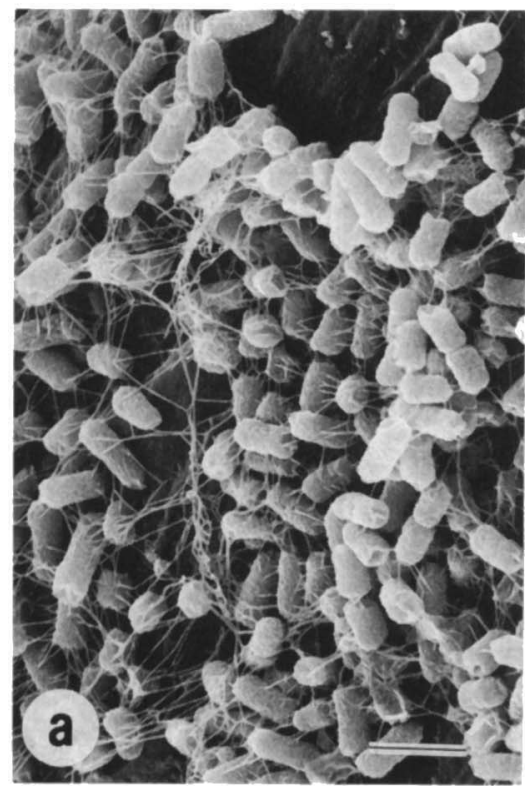

2

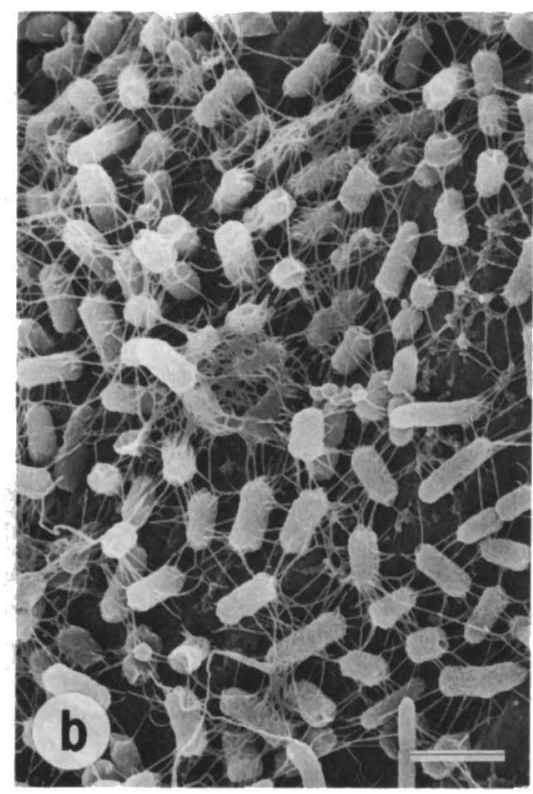

3

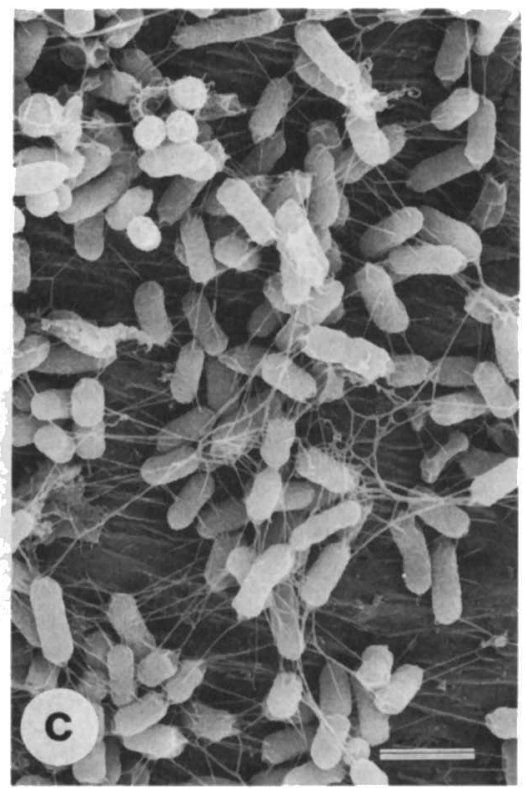

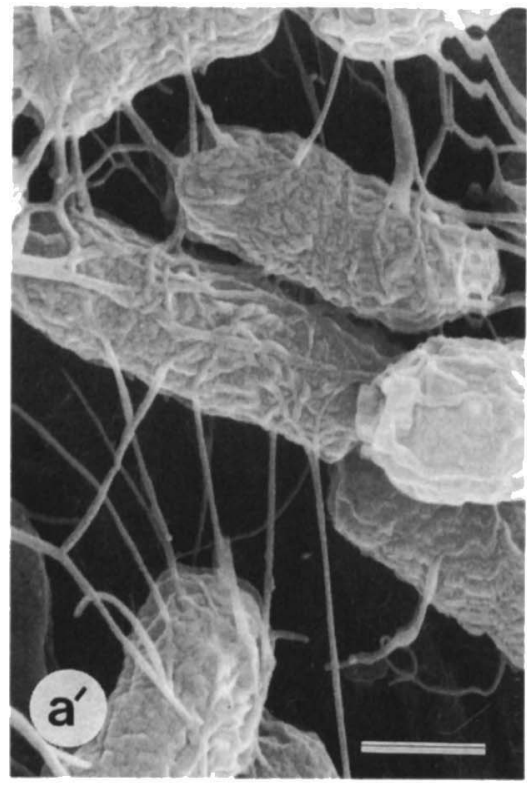
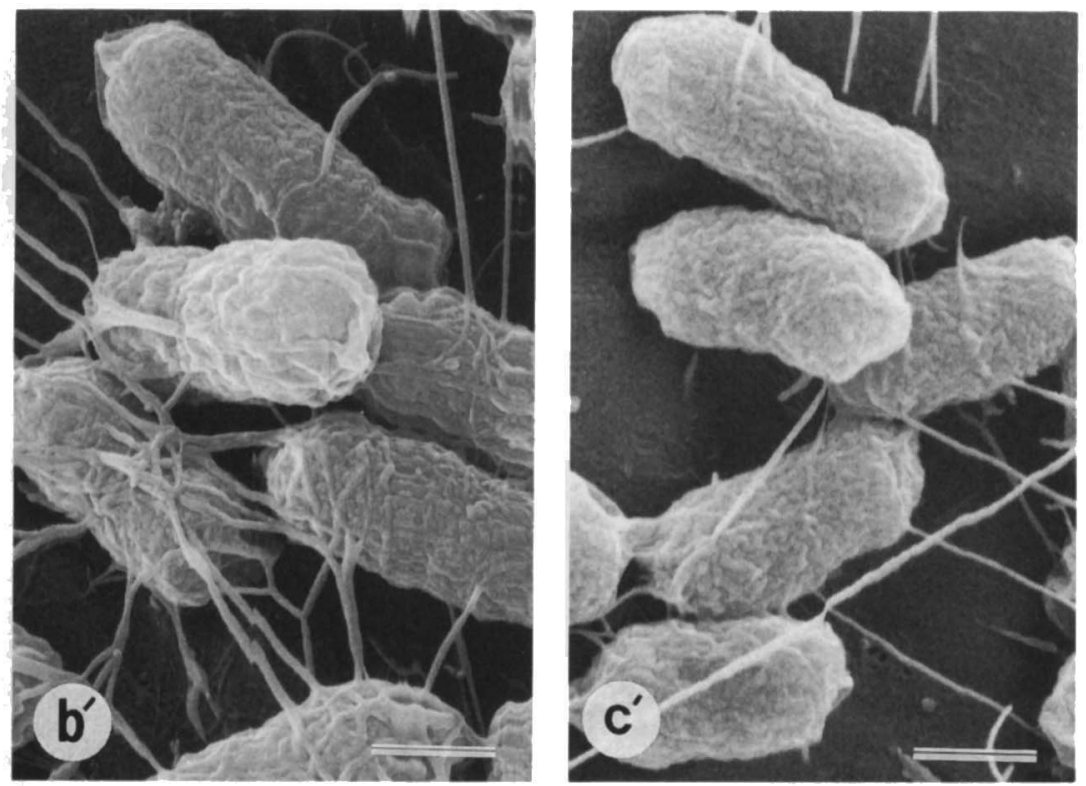

Fig. 4. In-vitro biofilm growth of $E$. coli on the surface of cotton threads in TSB. Scanning electronmicrographs of the surface of cotton threads after $0\left(\mathbf{a}, \mathbf{a}^{\prime}\right), \mathrm{I}\left(\mathbf{b}, \mathbf{b}^{\prime}\right)$ and $2\left(\mathbf{c}, \mathbf{c}^{\prime}\right)$ transfer repetitions in TSB. Bars in $\mathbf{a}, \mathrm{b}, \mathbf{c}$ and $\mathbf{a}^{\prime}, \mathbf{b}^{\prime}, \mathrm{c}^{\prime}$ are equivalent to $2 \mu \mathrm{m}$ and $0.5 \mu \mathrm{m}$, respectively.

figures, $\mathrm{a}, \mathrm{b}$, and $\mathrm{c}$ had undergone 0,1 and 2 transfer repetitions, respectively. Figs. $4 a^{\prime}-c^{\prime}$ and $5 a^{\prime}-c^{\prime}$ are electronmicrographs of bacteria in the biofilm corresponding to figs. $4 \mathrm{a}-\mathrm{c}$ and figs $5 \mathrm{a}-\mathrm{c}$.

The structure of the biofilm formed in vitro in CMC pouch exudate and the structure of the surface of bacteria in the biofilm resembled those observed in vivo in the infected pouches. However, they differed from those formed during growth in TSB.

\section{Sensitivity of PB to killing by phagocytes}

The sensitivity of PB released from biofilms formed in vitro on the surface of cotton threads in the pouch exudate (PB-Pouch) or TSB (PB-TSB) to killing by human PMNL is shown in fig. 6. The number of control bacteria decreased to $c .1 \%$ after incubation for $2 \mathrm{~h}$ with PMNL. However, PB from both sources showed almost the same degree of resistance to killing 


\section{Transfer repetitions}

0
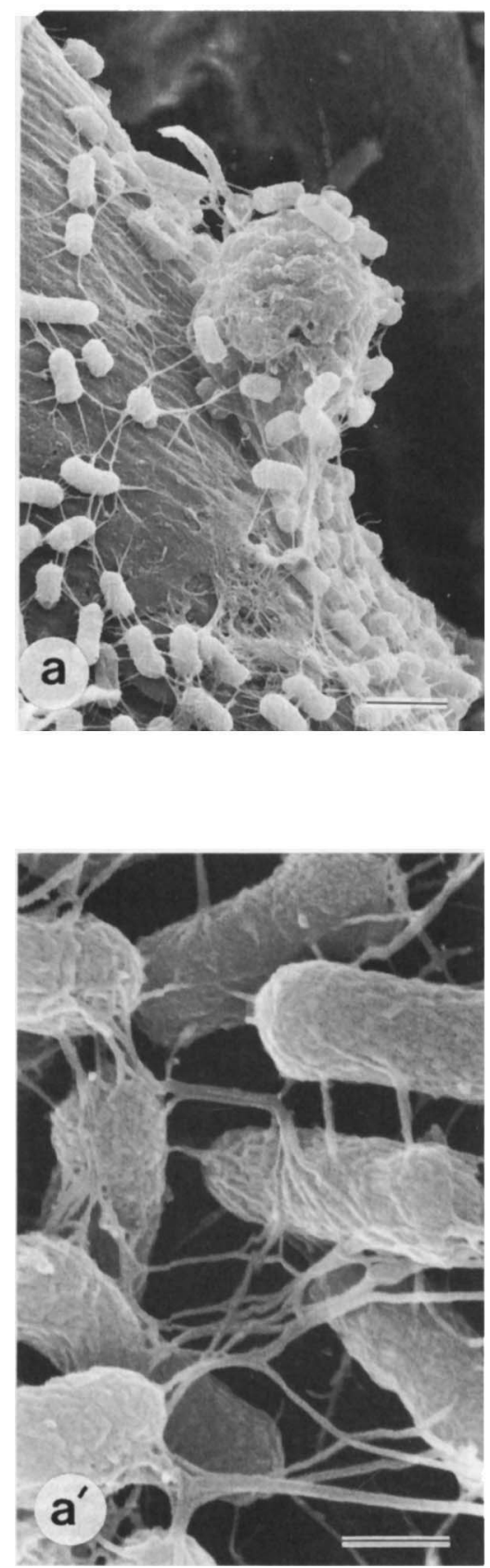

2
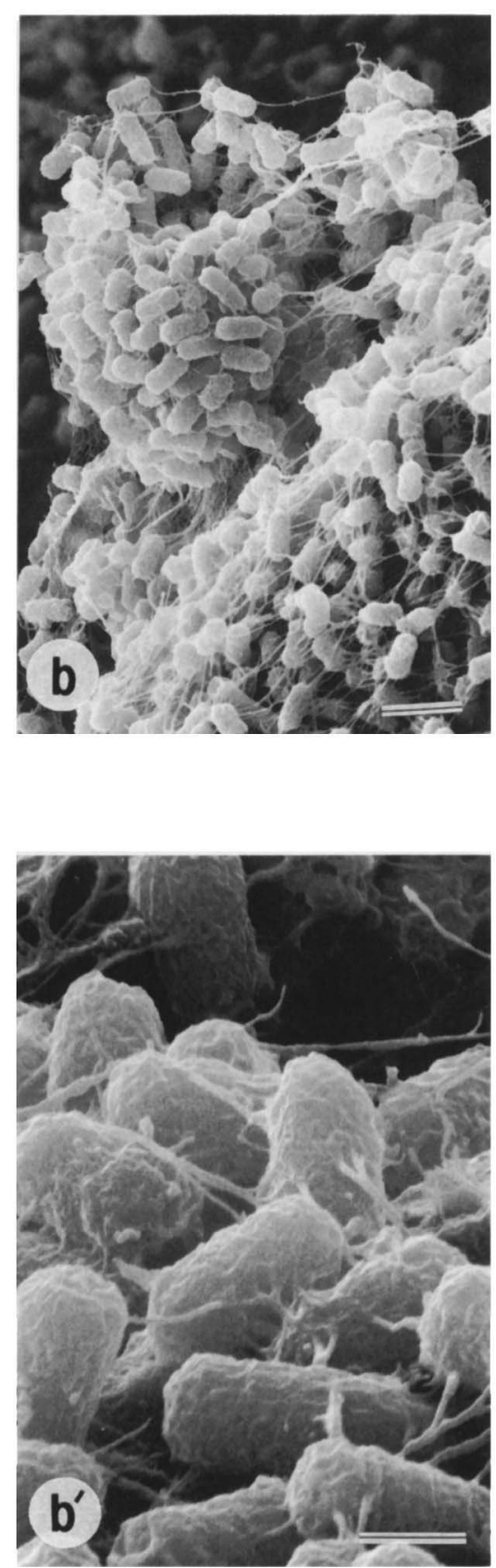

3
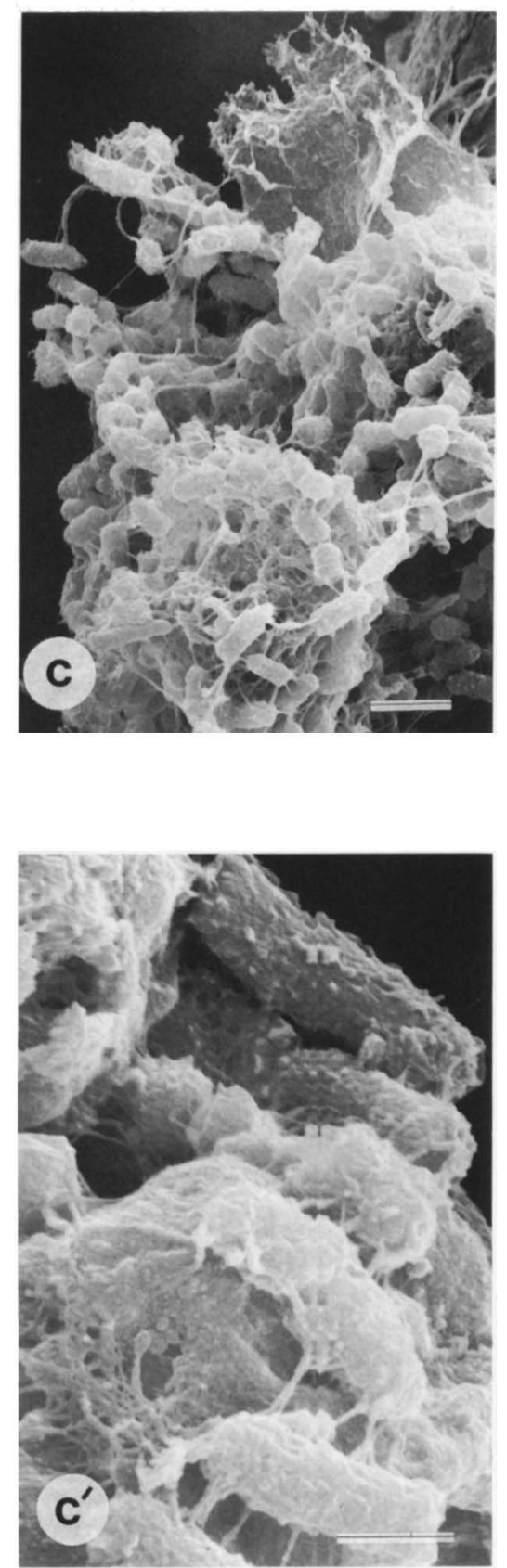

Fig. 5. In-vitro biofilm growth of $E$. coli on the surface of cotton threads in pouch exudate. Scanning electronmicrograph of the surface of cotton threads after $0\left(\mathbf{a}, \mathbf{a}^{\prime}\right), 1\left(\mathbf{b}, \mathbf{b}^{\prime}\right)$ and $2\left(\mathbf{c}, \mathbf{c}^{\prime}\right)$ transfer repetitions in pouch exudate. Bars in figs. $a, b, c$ and $a^{\prime}, b^{\prime}, c^{\prime}$ are equivalent to $2 \mu \mathrm{m}$ and $0.5 \mu \mathrm{m}$. respectively.

by PMNL. The rates of growth of PB and control bacteria did not differ from each other.

\section{Susceptibility of $P B$ to phagocytosis}

The results of phagocytosis experiments are shown in the table. The control bacteria and both PB-Pouch and PB-TSB were almost equally sensitive to phago- cytosis by PMNL. The differences in the percentage of phagocytosing PMNL and the mean number of bacteria/phagocytosing PMNL among the three groups of bacteria were not statistically significant.

Sensitivity of $P B$ to killing by $\mathrm{H}_{2} \mathrm{O}_{2}$

The sensitivity of PB to killing by $\mathrm{H}_{2} \mathrm{O}_{2} 0.01 \%$ and 


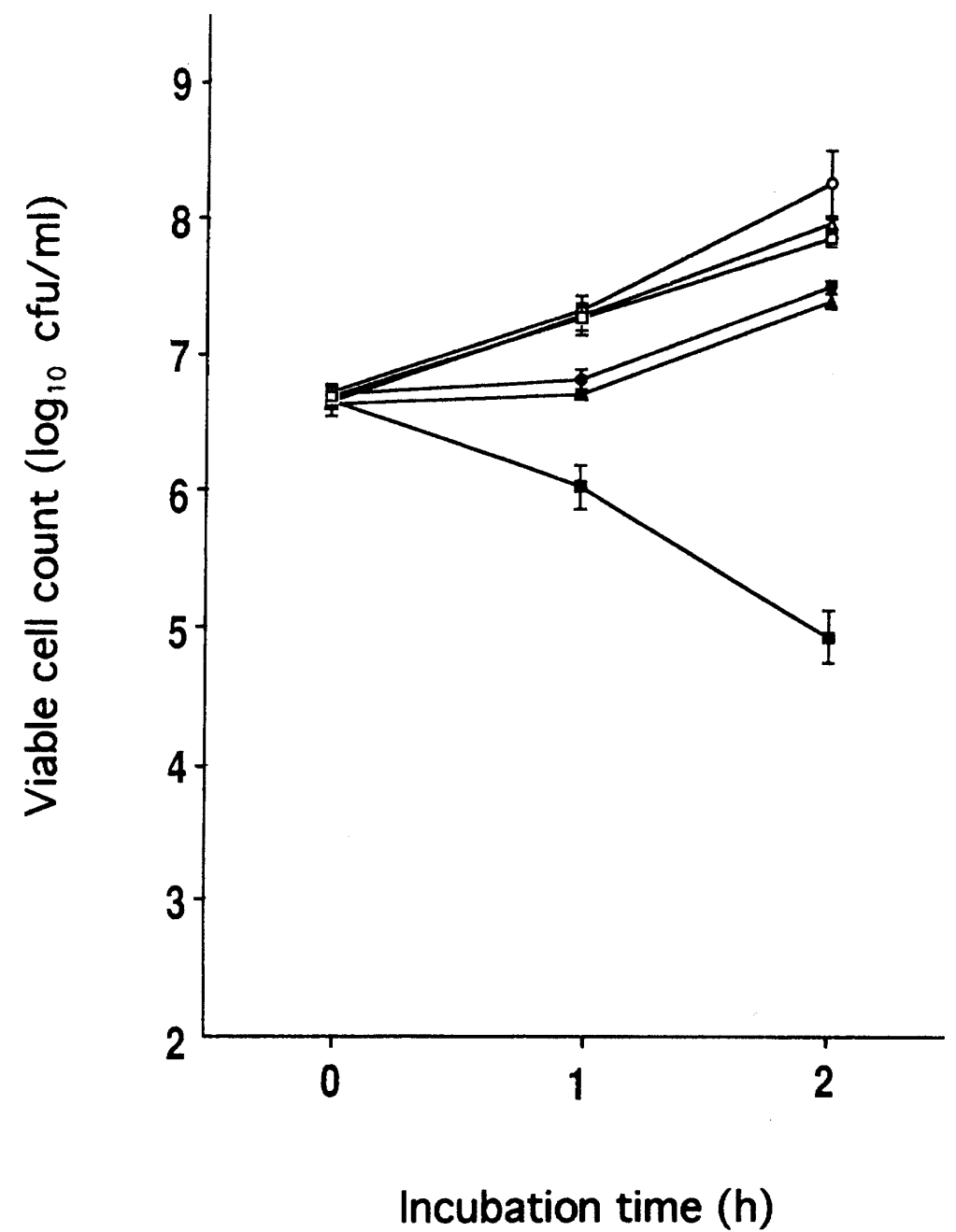

Fig. 6. Susceptibility of biofilm bacteria (PB) to killing by human PMNL. PB, c. $1 \times 10^{7} \mathrm{cfu}$, were mixed with $2 \times 10^{7} \mathrm{PMNL}$ in EBM containing human serum and incubated at $37^{\circ} \mathrm{C}$; after 1 and $2 \mathrm{~h}$, the numbers of viable bacteria were counted. $\mathrm{PB}-\mathrm{Pouch}+\mathrm{PMN} ; \mathrm{O}, \mathrm{PB}-$ Pouch; $\boldsymbol{\Delta}$, PB-TSB + PMN; $\triangle$, PB-TSB; $\boldsymbol{\square}$, control + PMN; $\square$, control.

Table. Susceptibility of biofilm bacteria (PB) to phagocytosis by PMNL

\begin{tabular}{|c|c|c|c|c|c|c|}
\hline \multirow{2}{*}{$\begin{array}{c}\text { Experiment } \\
\text { no. }\end{array}$} & \multicolumn{2}{|c|}{ Pouch } & \multicolumn{2}{|c|}{ TSB } & \multicolumn{2}{|c|}{ Control } \\
\hline & A & B & A & B & A & B \\
\hline 1 & 35 & $2 \cdot 6$ & 44 & $3 \cdot 2$ & 43 & 3.4 \\
\hline 2 & 33 & 2.4 & 35 & 3.0 & 40 & 3.4 \\
\hline 3 & 22 & 2.8 & 29 & 2.6 & 25 & 2.9 \\
\hline 4 & 20 & 2.8 & 27 & $3 \cdot 1$ & 19 & 3.2 \\
\hline 5 & 37 & 4.9 & 38 & $3 \cdot 1$ & 48 & $5 \cdot 4$ \\
\hline Mean (SE) & $29(3 \cdot 5)$ & $3.1(0.46)$ & $35(3 \cdot 1)$ & $3 \cdot 0(0 \cdot 11)$ & $35(5 \cdot 5)$ & $3.7(0.44)$ \\
\hline
\end{tabular}

A, number of phagocytosing cells/100 PMNL; B, mean bacterial number/phagocytosing cell.

$0.001 \%$ is shown in fig. 7. PB-Pouch and PB-TSB showed almost the same degree of resistance to killing.

\section{Transmission electronmicroscopy of $P B$}

Figs. $8 \mathrm{a}, \mathrm{b}$ and $\mathrm{c}$ are, respectively, transmission electronmicrographs of PB-Pouch, PB-TSB, and control bacteria. The surfaces of both types of $\mathrm{PB}$ were covered with substances that bound ruthenium red, although there was much more of these substances on the surfaces of PB-Pouch than on PB-TSB. Such substances were not found on the surface of the control bacteria.

\section{Discussion}

In the bacterial infection model of CMC pouches on the backs of rats, biofilms of complicated structure were formed on the surface of subcutaneous tissue. Electronmicrographs of the biofilms suggested that blood cells, other cells and some components of tissue 


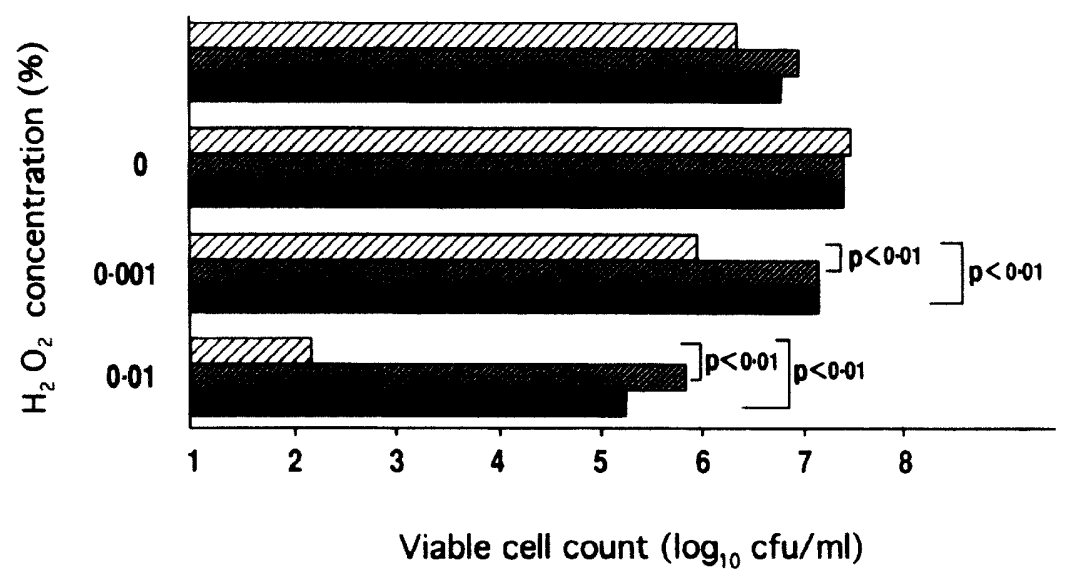

Fig. 7. Susceptibility of biofilm bacteria (PBS) to killing by $\mathrm{H}_{2} \mathrm{O}_{2}$. PB, c. $4 \times 10^{6} \mathrm{cfu} / \mathrm{ml}$ in TSB, were mixed with $\mathrm{H}_{2} \mathrm{O}_{2}$. The numbers of viable bacteria were counted after incubation at $37^{\circ} \mathrm{C}$ for $1 \mathrm{~h}$. $\mathrm{DB}$.Pouch; , PB-TSB, $\square$, control.
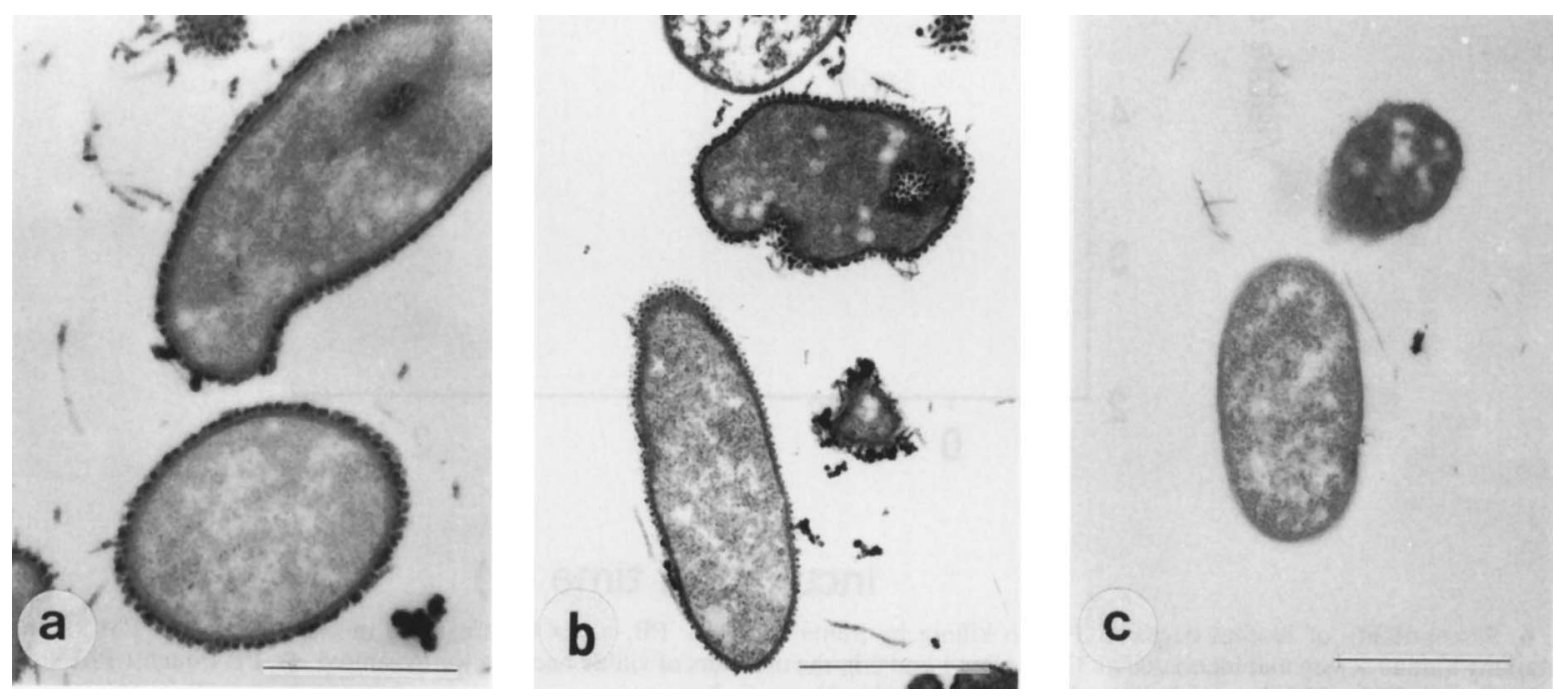

Fig. 8. Transmission electronmicrograph of $\mathrm{PB}$ and control bacteria. $\mathbf{a}, \mathbf{P B}$ released from biofilm formed in the pouch exudate; $\mathbf{b}$, PB released from biofilm in TSB : c, control bacteria. Bars are equivalent to $1 \mu \mathrm{m}$.

fluid have important roles in the formation of biofilms. Bacterial biofilms that result in chronic or refractory infections are probably constructed in tissues or on the surface of biomaterials by way of highly complicated mechanisms. $^{2 \cdot 2}$

In this report, interactions between human PMNL and bacteria released from two bacterial biofilm models that were formed in vitro in different media were compared. One model was formed in an artificial medium. TSB, and the other in rat CMC pouch exudate. The structure of the biofilm formed in the pouch exudate and the surface structure of bacteria in the biofilm were similar to those observed in the infected CMC pouches, but they were quite different from those observed with bacteria from the biofilm model formed in the artificial medium, TSB.

Both PB-Pouch and PB-TSB showed significant resistance to killing by human PMNL, but they were as sensitive to phagocytosis by PMNL as the control bacteria. The significant increase in resistance of both PB to killing by $\mathrm{H}_{2} \mathrm{O}_{2}$ clearly suggested that the increase in resistance of $\mathrm{PB}$ to killing by PMNL was caused by an increase in resistance of $P B$ to killing by active oxygen species in PMNL. No significant differences in resistance to killing by PMNL and $\mathrm{H}_{2} \mathrm{O}_{2}$ were found between PB-Pouch and PB-TSB.

Transmission electronmicrographs showed that both PB were covered with some substances that bound ruthenium red, although PB-Pouch had more of these surface substances than PB-TSB. However, such substances were not found on the surface of the control bacteria.

From these experimental data, it may be reasonable to speculate as follows: (1) E. coli strain 704, cells change to produce substances (acidic polysaccharides) that bind ruthenium red on their surfaces when they adhere to the surface of threads in pouch exudate or TSB, although the quantity of such substances changes according to the medium used. (2) The differences in appearance between bacteria in biofilms formed on the surface of threads in pouch exudate and TSB observed by scanning electronmicroscopy may have resulted from quantitative differences of acidic polysaccharides, i.e., acidic polysaccharides, coupled with some components in the pouch exudate, may be necessary for the development of bacterial biofilms in 
vivo. (3) Bacteria may acquire resistance to killing by active oxygen species produced by PMNL by production of acidic polysaccharides. However, it may be reasonable to state that the production of acidic polysaccharides is not a direct cause of the resistance, because the resistance seemed not to depend on the quantity of polysaccharide. (4) The presence of acidic polysaccharides on the surface of an individual bacterium released from a biofilm might not influence phagocytosis by PMNL. However, it is possible that a large quantity of polysaccharides influences phagocytosis by PMNL; Simon et al. ${ }^{23}$ reported that a strain of Bacteroides fragilis, which is covered with capsular polysaccharide, was significantly more resistant to phagocytosis by neutrophils. Johnson et al. ${ }^{17}$ showed that bacteria adhering to a plastic surface and producing slime were more resistant to uptake by PMNL than bacteria that did not produce slime. Adherent bacteria, as well as bacteria buried in slime, might resist phagocytosis by PMNL by some additional mechanisms.

Many reports have indicated some differences between bacteria grown in vitro and in vivo. Passage of Neisseria gonorrhoeae in plastic chamber implants resulted in increased resistance to complementmediated serum killing and phagocytosis. ${ }^{18,24}$ There were differences between the envelope-protein profiles of $E$. coli grown in vivo and in vitro. ${ }^{25}$ However, our findings here, that bacteria grown on the surface of cotton threads in pouch exudate and in TSB had increased resistance to killing by phagocytes, indicate that the increase in resistance was caused by adhesion of bacteria and not by a difference in growth medium. The increase in resistance of biofilm bacteria to killing by phagocytes may result from some changes in the bacteria caused by adhesion. The mechanisms by which adherent bacteria change to produce polysaccharides on their surfaces are still to be investigated.

\section{References}

1. Warren JW, Muncie HL, Bergquist EJ, Hoopes JM. Sequelae and management of urinary infection in the patient requiring chronic catheterization. $J$ Urol $1981 ; 125$ : 1-8.

2. Nickel JC, Ruseska I, Wright JB, Costerton JW. Tobramycin resistance of cells of Pseudomonas aeruginosa growing as a biofilm on urinary catheter material. Antimicrob Agents Chemother 1985; 27: 619-624.

3. La Tourette Prosser B, Taylor D, Dix BA, Cleeland R. Method of evaluating effects of antibiotics on bacterial biofilm. Antimicrob Agents Chemother 1987; 31: 1502-1506.

4. Costerton JW, Nickel JC, Marrie TJ. The role of the bacterial glycocalyx and of the biofilm mode of growth in bacterial pathogenesis. Roche Sem Bacteriol 1985; 2: 1-25.

5. Dickinson GM, Bisno AL. Infections associated with indwelling devices: concepts of pathogenesis; infections associated with intravascular devices. Antimicrob Agents Chemother 1989; 33: 597-601.

6. Widmer AF, Wiestner A, Frei R, Zimmerli W. Killing of nongrowing and adherent Escherichia coli determines drug efficacy in device-related infections. Antimicrob Agents Chemother 1991; 35: 741-746.

7. Lam J, Chan R, Lam K, Costerton JW. The production of mucoid microcolonies by Pseudomonas aeruginosa within infected lungs in cystic fibrosis. Infect Immun 1980; 28: 546-556.

8. Mayberry-Carson KJ, Tober-Meyer B, Smith JK, Lambe DW, Costerton JW. Bacterial adherence and glycocalyx formation in osteomyelitis experimentally induced with Staphylococcus aureus. Infect Immun 1984; 43: 825-833.

9. Marrie TJ, Costerton JW. Mode of growth of bacterial pathogens in chronic polymicrobial human osteomyelitis. $J$ Clin Microbiol 1985; 22: 924-933.

10. Ajiki $\mathrm{Y}, \mathrm{Koga} \mathrm{T}$, Ohya $\mathrm{S}$ et al. $\beta$-Lactamase produced by a highly $\beta$-lactam-resistant strain of Bacteroides fragilis: an obstacle to the chemotherapy of experimental mixed infections. J Antimicrob Chemother 1991; 28: 537-546.

11. Gristina AG, Hobgood CD, Webb LX, Myrvik QN. Adhesive colonization of biomaterials and antibiotic resistance. Biomaterials 1987; 8: 423-426.

12. Farber BF, Kaplan MH, Clogston AG. Staphylococcus epidermidis extracted slime inhibits the antimicrobial action of glycopeptide antibiotics. $J$ Infect Dis $1990 ; 161: 37-40$.

13. Chuard C, Lucet JC, Rohner P et al. Resistance of Staphylococcus aureus recovered from infected foreign body in vivo to killing by antimicrobials. $J$ Infect Dis 1991; 163: 1369-1373.

14. Evans DJ, Allison DG, Brown MRW, Gilbert P. Susceptibility of Pseudomonas aeruginosa and Escherichia coli biofilms toward ciprofloxacin: effect of specific growth rate. $J$ Antimicrob Chemother 1991; 27 : 177-184.

15. Gray ED, Peters G, Verstegen M, Regelmann WE. Effect of extracellular slime substance from Staphylococcus epidermidis on the human cellular immune response. Lancet 1984; 1 : 365-367.

16. Vaudaux PE, Zulian G, Huggler E, Waldvogel FA. Attachment of Staphylococcus aureus to polymethylmethacrylate increases its resistance to phagocytosis in foreign body infection. Infect Immun $1985 ; \mathbf{5 0}: 472-477$.

17. Johnson GM, Lee DA, Regelmann WE, Gray ED, Peters G, Quie PG. Interference with granulocyte function by Staphylococcus epidermidis slime. Infect Immun 1986; 54: 13-20.

18. Penn $\mathrm{CW}$, Veale $\mathrm{DR}$, Smith $\mathrm{H}$. Selection from gonococci grown in vitro of a colony type with some virulence properties of organisms adapted in vivo. J Gen Microbiol 1977; 100: $147-158$.

19. Gilbert P, Allison DG, Evans DJ, Handley PS, Brown MRW. Growth rate control of adherent bacterial populations. Appl Environ Microbiol 1989; 55: 1308-1311.

20. Allison DG, Evans DJ, Brown MRW, Gilbert P. Possible involvement of the division cycle in dispersal of Escherichia coli from biofilms. $J$ Bacteriol 1990; 172: 1667-1669.

21. Zimmerli W, Lew PD, Waldvogel FA. Pathogenesis of foreign body infection. Evidence for a local granulocyte defect. $J$ Clin Invest 1984; 73 : 1191-1200.

22. Buret A, Ward KH, Olson ME, Costerton JW. An in-vivo model to study the pathobiology of infectious biofilms on biomaterial surfaces. J Biomed Mater Res 1991; 25: 865-874.

23. Simon GL, Klempner MK, Kasper DL, Gorbach SL. Alterations in opsonophagocytic killing by neutrophils of Bacteroides fragilis associated with animal and laboratory passage: Effect of capsular polysaccharide. $J$ Infect Dis 1982; 145: 72-77.

24. Penn CW, Sen D, Veale DR, Witt K, Parsons NJ, Morphological, biological and antigenic properties of Neisseria gonorrhoeae adapted to growth in guinea-pig subcutaneous chambers. J Gen Microbiol 1976; 97: 35-43.

25. Finn TM, Arbuthnott JP, Dougan G. Properties of Escherichia coli grown in vivo using a chamber implant system. J Gen Microbiol 1982; 128 : 3083-3091. 